\title{
Methotrexate Displacement in Man*
}

\author{
D. G. Johns, $†$ J. W. Hollingsworth, A. R. Cashmore, I. H. Plender- \\ LEITH, $\frac{\ddagger}{\ddagger}$ AND J. R. BERTINO \\ (From the Departments of Pharmacology and Medicine, Yale University School of Medicine. \\ New Haven, Conn.)
}

In a number of mammalian species, including man, the 4-amino analogs of pteroylglutamate persist in liver and kidney for many months after administration (1-4). In the rat (3) and mouse (4), the binding site appears to be the enzyme dihydrofolate reductase [also termed folate reductase (5) and tetrahydrofolate dehydrogenase. ${ }^{1}$ ] Studies with partially purified dihydrofolate reductase obtained from several sources (6-8) have shown the affinity of this enzyme for the 4-amino analogs to be extremely high.

Recent work with tritium-labeled pteroylglutamate in vivo has shown that, in man, the labeled compound can be displaced from cells several days after its administration, both by unlabeled pteroylglutamate $(9,10)$ and by other compounds that possess an affinity for the enzyme dihydrofolate reductase (11). If, as animal experiments suggest, the 4-amino analogs bind to the same enzyme, a similar procedure should also bring about the displacement of these compounds. The studies reported here show that, in man, tritiated methotrexate (amethopterin ; 4-amino- $N^{10}$-methylpteroylglutamic acid) can be readily displaced

* Submitted for publication October 7, 1963; accepted November 29, 1963.

This investigation was supported in part by a U. S. Public Health Service research grant (CA-02817) and in part by a research grant from the Lederle Laboratories Division, American Cyanamid Co., Pearl River, N. Y. Some of the experimental subjects were studied in the Yale Clinical Research Center, supported by a grant (FR38-03) of the U. S. Public Health Service.

† Research fellow of the National Cancer Institute of Canada and of Yale University (U. S. Public Health Service research training grant 5-T1-GM-59-04).

$\ddagger$ Present address: The Princess Margaret Hospital, Toronto, Canada.

1 The latter is the trivial name suggested by the Enzyme Commission of the International Union of Biochemistry. The suggested systematic name for the enzyme is $5,6,7,8$-tetrahydrofolate: $\mathrm{DPN}^{+}\left(\mathrm{TPN}^{+}\right)$oxidoreductase, E.C. 1.5.1.3. unchanged by unlabeled compounds having an affinity for the enzyme; however, an unexpected additional finding was that the trace amount of radioactivity appearing in the urine before administration of the flushing doses was the result, in large part, of the excretion of two previously unreported labeled metabolites. It is postulated, therefore, that the gradual fall in tissue methotrexate seen in man after a single dose of the drug is attributable to the slow conversion of the compound to forms possessing a lower affinity than the parent compound for the enzyme dihydrofolate reductase.

\section{Methods}

Preparation of tritium-labeled methotrexate. Methotrexate $2(25 \mathrm{mg})$ was dissolved in tritiated acetic acid $(10 \mathrm{c} ; 10 \mathrm{ml})$ and heated overnight at $80^{\circ} \mathrm{C}$ in the presence of prereduced platinum catalyst $(25 \mathrm{mg}) .^{3}$ The solvent was removed by vacuum distillation. The residue was redissolved in sodium bicarbonate solution $(0.1 \mathrm{M})$ and chromatographed on DEAE-cellulose with neutral phosphate buffers by the method previously described for the preparation of tritium-labeled pteroylglutamate (9). Methotrexate concentration was determined by measuring optical density at $302 \mathrm{~m} \mu$ in a solution of sodium hydroxide $(0.1 \mathrm{~N})$ (12). Specific activity after chromatography was $778 \mathrm{mc}$ per mmole; additional chromatographic purification did not change this value. The chromatographed material was stored in sodium phosphate buffer $(0.2 \mathrm{M} ; \mathrm{pH} 6.95)$ in the dark at $5^{\circ} \mathrm{C}$. For intravenous administration, the required amount of tritiated methotrexate solution was diluted to $20 \mathrm{ml}$ with sterile normal saline and the resulting solution sterilized by filtration through a Millipore HA filter. ${ }^{4}$

Distribution of radioactivity within the methotrexatc molecule. Freshly chromatographed unlabeled methotrexate $(2.0 \mathrm{mg})$ was dissolved in sodium hydroxide solution $(0.05 \mathrm{~N} ; 2.0 \mathrm{ml})$ and added to tritium-labeled methotrexate $(202 \mu \mathrm{c} ; 0.15 \mathrm{ml})$ prepared in the manner

\footnotetext{
${ }^{2}$ Lederle Laboratories Division, American Cyanamid Co., Pearl River, N. Y.

3 Tritium exchange was carried out by the New England Nuclear Corp., Boston, Mass.

4 Millipore Filter Corp., Bedford, Mass.
} 
described. Hydrochloric acid $(5 \mathrm{~N} ; 1 \mathrm{ml})$ was added, followed by zinc dust $(200 \mathrm{mg})$, and reductive cleavage was allowed to proceed overnight. The mixture was centrifuged and the supernatant fraction extracted twice with 1-ml portions of liquefied phenol. The phenol extracts were combined and extracted with a mixture of water $(1 \mathrm{ml})$ and ether $(5 \mathrm{ml})$. The layers were allowed to separate, and the ether layer was discarded. The water layer was extracted twice more with fresh $5-\mathrm{ml}$ portions of ether, which were discarded. The aqueous layer, which contained the methotrexate cleavage products, was brought to neutrality with $0.1 \mathrm{~N}$ sodium hydroxide and chromatographed on DEAE-cellulose. The cleavage products were collected separately; the concentration of $N$-methyl- $p$-aminobenzoylglutamate was determined by measurement of the optical density at $283 \mathrm{~m} \mu$ at $\mathrm{pH} 7$, and that of the pteridine moiety by measurement of the optical density at $334 \mathrm{~m} \mu$ at $\mathrm{pH} 1$ (13). Radioactivity was determined by liquid scintillation counting ; distribution of the tritium label was $62 \%$ in the pteridine moiety and $38 \%$ in the $N$-methyl- $p$ aminobenzoylglutamate.

Stability of stored tritiated methotrexate. The stored methotrexate- ${ }^{3} \mathrm{H}$ was rechromatographed on DEAE-cellulose 3 months after the completion of the studies described below and 5 months after the initial chromatographic purification. The radioactivity of the eluate was determined by liquid scintillation counting; $96.1 \%$ of the radioactivity applied to the DEAE-cellulose column migrated as unchanged methotrexate.

Counting methods. A Packard Tri-Carb liquid scintillation counter was used for all tritium assays. A modified dioxane-naphthalene scintillator $(14,15)$ was used: 1,4-bis-2-(5-phenyloxazolyl) benzene (POPOP) ${ }^{5} \quad(250$ $\mathrm{mg})$ and 2,5-diphenyloxazole $5(10 \mathrm{~g})$ were dissolved in reagent grade dioxane $(770 \mathrm{ml})$; the volume of the solution was brought to $1,000 \mathrm{ml}$ with absolute ethanol, and naphthalene $(100 \mathrm{~g})$ was then added. Fifteen $\mathrm{ml}$ of scintillator solution was used in each counting vial. Plasma samples were diluted 1:10 with distilled water, and $0.5-\mathrm{ml}$ samples of the resulting solution were used for counting; $0.5-\mathrm{ml}$ samples of urine were pipetted directly into the scintillator. All samples were counted in duplicate and corrected for quenching by recounting after the addition of internal standard. 6

Chromatographic methods. Highly radioactive urines were chromatographed directly on DEAE-cellulose columns $(1 \times 7 \mathrm{~cm})$ with neutral sodium phosphate buffers, by methods developed for the separation and identification of urine radioactivity after the administration of tritium-labeled pteroylglutamate $(9)$. Samples $(0.5 \mathrm{ml})$ of the fractions obtained were counted by the method described above for the counting of urines.

Weakly radioactive urines could not be handled by the same method, since the radioactivity present in the fractions eluted from the columns was too low to yield

5 Pilot Chemicals Inc., Watertown, Mass.

6 Tritiated toluene, New England Nuclear Corp., Boston, Mass. significant values during a reasonable counting period. In these instances, the radioactive products present were extracted and concentrated before chromatography, as follows: $1 \mathrm{ml}$ of an aqueous solution of unlabeled carrier methotrexate $(1 \mathrm{mg}$ per $\mathrm{ml}$ ) was added to $50 \mathrm{ml}$ of urine immediately after collection; $5 \mathrm{ml}$ of concentrated hydrochloric acid was then added, and the urine was extracted twice with $10-\mathrm{ml}$ portions of liquefied phenol. The phenol extracts were combined and extracted with a mixture of $5 \mathrm{ml}$ of water and $20 \mathrm{ml}$ of ether. The ether layer was discarded and the aqueous layer extracted twice more with $20-\mathrm{ml}$ portions of ether, which were discarded. The aqueous layer was brought to neutral $\mathrm{pH}$ with $0.1 \mathrm{~N}$ sodium hydroxide solution and applied directly to a DEAE-cellulose column.

To determine whether methotrexate was stable under the conditions of extraction, $5 \mu \mathrm{c}(2.91 \mu \mathrm{g})$ of tritiumlabeled methotrexate was added to $50 \mathrm{ml}$ of urine, which was then extracted as described above. On chromatography, $99.6 \%$ of the radioactivity applied to the column migrated as unchanged methotrexate. Recovery exceeded $90 \%$.

Displacing agents. Pteroylglutamate, methotrexate, and $d l, \mathrm{~L}-5$-formyltetrahydropteroylglutamate (folinic acid; citrovorum factor) ${ }^{2}$ were purified by column chromatography on DEAE-cellulose. Crystalline dihydropteroyl-glutamate was prepared by the method of Futterman (16), as modified by Blakley (17). l,L-5Methyltetrahydropteroylglutamate (prefolic A) was synthesized from enzymatically prepared $l, \mathrm{~L}$-tetrahydropteroylglutamate (18) by a modification of the procedures of Keresztesy and Donaldson (19) and of Sakami and Ukstins (20). For intravenous administration, these compounds were dissolved in isotonic sodium bicarbonate and sterilized by filtration through a Millipore filter.

Urine collections. Complete collections of urine were made from the time of administration of tritium-labeled methotrexate until after the completion of all displacement experiments, a period of from 3 to 5 weeks.

Experimental subjects. Subjects were normal volunteers or hospital patients free from neoplastic or renal disease. All subjects received $2.5 \mu \mathrm{g}$ per $\mathrm{kg}$ of tritiumlabeled methotrexate $(250$ to $375 \mu \mathrm{c}$ ) in a single $20-\mathrm{ml}$ iv injection, with the exception of subject M.O., who received the drug in a $1,000-\mathrm{ml}$ saline infusion over a period of 5 hours.

\section{Results}

Plasma clearance and renal excretion of labeled methotrexate. After the intravenous administration of $2.5 \mu \mathrm{g}$ of tritium-labeled methotrexate per $\mathrm{kg}$, the levels of radioactivity in the plasma and urine declined slowly (Figures 1 and 2); a steady state was not reached until some 48 hours after the initial dose. The total urinary excretion of radioactivity during this period ranged from 37.8 to $55.6 \%$ of the administered dose in the four 
subjects studied; thereafter, however, the rate of urinary excretion was extremely slow, amounting only to from 1 to $2 \%$ of the retained dose per day, and plasma levels were only slightly above background. Chromatography of the urines, described more fully in a later section, revealed that the radioactivity excreted during the first 48 hours consisted almost entirely of unchanged methotrexate, but that much of the radioactivity appearing in the urine subsequent to this period was attributable to compounds other than methotrexate.

Urinary excretion of radioactivity after displacement. At least 2 weeks was allowed to elapse after the initial dose of labeled methotrexate before displacement studies were carried out. Three types of compound were tested for ability to displace labeled methotrexate from cells: $a$ ) the unreduced compounds, pteroylglutamate and methotrexate; $b$ ) the partially reduced compound, dihydropteroylglutamate; and $c$ ) the fully reduced compounds, 5-methyl- and 5-formyltetrahydropteroylglutamate. Unlabeled methotrexate proved to be an extremely effective displacing agent, while dihydropteroylglutamate and pteroylglutamate were only moderately effective, and the tetrahydro compounds displaced only trace amounts of radioactivity (Table $\mathrm{I}$ ).

Partial displacement of radioactivity by one agent did not preclude subsequent additional displacement of radioactivity with either the same

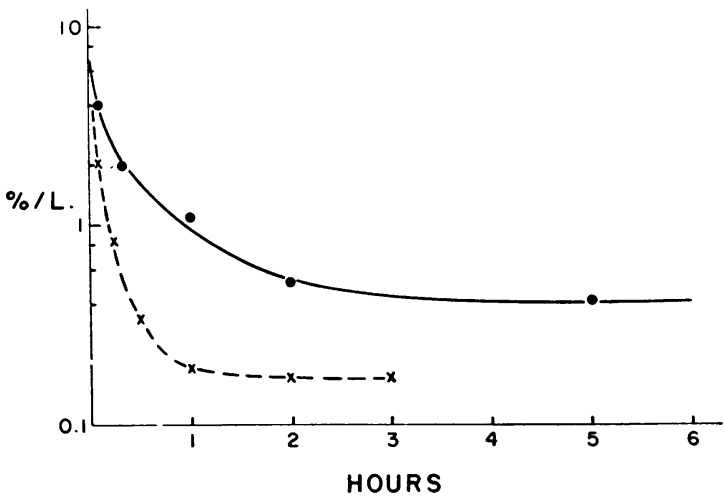

Fig. 1. Plasma radioactivity (Subject E.B.) after THE INTRAVENOUS INJECTION OF $2.5 \mu \mathrm{G}$ OF TRITIUM-LABELED METHOTREXATE PER KG $(290 \mu \mathrm{C})$. Ordinate: percentage of injected dose per liter of plasma. For purposes of comparison, the radioactivity in the plasma after an equimolar dose of tritium-labeled folic acid is indicated by the broken line (data derived from reference 9).

or another agent; for example (Subject M.O., Table I and Figure 3), $30 \mathrm{mg}$ of unlabeled pteroylglutamate displaced $5.8 \%$ of retained ${ }^{7}$ radioactivity 22 days after the initial dose and a further

\footnotetext{
${ }^{7}$ Retained dose was calculated by subtracting the cumulative urinary excretion of radioactivity from the initial dose; if excretion of small amounts of radioactivity took place by additional routes (e.g., the bile), the actual retained dose would be less and, thus, values for percentage of displacement greater than indicated.
}

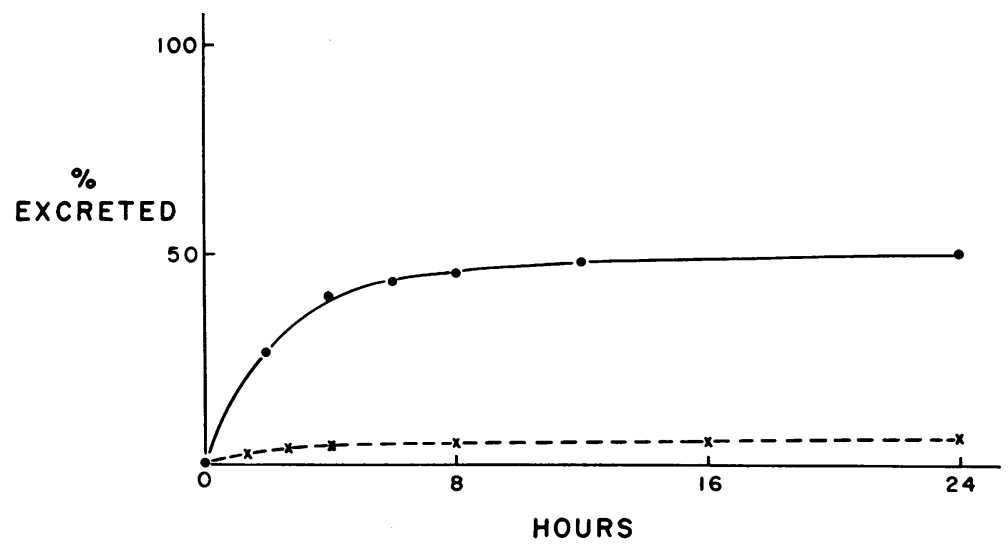

Fig. 2. Urinary excretion of Methotrexate radioactivity (SUbJect E.B.) AFTER THE INTRAVENOUS INJECTION OF $2.5 \mu \mathrm{G}$ OF TRITIUM-LABELED METHOTREXATE PER KG $(290 \mu \mathrm{C})$. Ordinate: cumulative excretion of radioactivity in the urine as a percentage of the injected dose. For purposes of comparison, the radioactivity in the urine after an equimolar dose of tritiumlabeled folic acid is indicated by the broken line (data derived from reference 9). 
TABLE I

Displacement of tritium-labeled methotrexate

\begin{tabular}{|c|c|c|c|c|}
\hline Subject & Displacing agent & $\begin{array}{l}\text { Time between } \\
\text { initial dose } \\
\text { of methotrex- } \\
\text { ate--3H and } \\
\text { flushing dose }\end{array}$ & $\begin{array}{l}\text { Displacement* } \\
\% \text { of original } \\
\text { dose }\end{array}$ & $\begin{array}{l}\text { Displacement } \\
\% \text { of retained } \\
\text { doset }\end{array}$ \\
\hline \multirow{4}{*}{ M.O. } & & days & $\%$ & $\%$ \\
\hline & $\begin{array}{l}\text { Pteroylglutamate, } \\
30 \mathrm{mg}\end{array}$ & 21 & 2.8 & 5.8 \\
\hline & $\begin{array}{l}\text { Pteroylglutamate, } \\
30 \mathrm{mg}\end{array}$ & 24 & 1.9 & 4.2 \\
\hline & $\begin{array}{l}\text { Methotrexate, } \\
30 \mathrm{mg}\end{array}$ & 26 & 13.6 & 32.0 \\
\hline \multirow[t]{2}{*}{ P.C. } & $\begin{array}{l}\text { l,L-5-Methyltetra- } \\
\text { hydropteroylglu- } \\
\text { tamate, } 7 \mathrm{mg}\end{array}$ & 16 & 0.1 & 0.4 \\
\hline & $\begin{array}{l}\text { Methotrexate, } \\
10 \mathrm{mg}\end{array}$ & 18 & 12.1 & 67.7 \\
\hline \multirow[t]{3}{*}{ E.B. } & $\begin{array}{l}\text { Dihydropteroyl- } \\
\text { glutamate, } 10 \mathrm{mg}\end{array}$ & 18 & 3.2 & 13.8 \\
\hline & $\begin{array}{l}\text { Pteroylglutamate, } \\
10 \mathrm{mg}\end{array}$ & 19 & 1.2 & 6.2 \\
\hline & $\begin{array}{l}\text { Methotrexate, } \\
10 \mathrm{mg}\end{array}$ & 20 & 9.6 & 59.1 \\
\hline \multirow[t]{2}{*}{ J.B. } & $\begin{array}{l}d l, \text { L-5-Formyl- } \\
\text { tetrahydro- } \\
\text { pteroylglutamate, } \\
30 \mathrm{mg}_{\ddagger}^{\ddagger}\end{array}$ & 29 & 0.4 & 1.4 \\
\hline & $\begin{array}{l}\text { Pteroylglutamate, } \\
30 \mathrm{mg}\end{array}$ & 32 & 2.5 & 9.1 \\
\hline
\end{tabular}

* Duration of the displacement effect was taken as the period from the administration of the flushing dose to the time when the rate of urinary excretion of radioactivity returned to the base-line level (a period of usually slightly over 24 hours; see Figure 3). The radioactivity excreted over a control period of equivalent duration immediately before the administration of the flushing dose was then subtracted from the total urinary radioactivity after the flush, in order to give net radioactivity displaced.

$\dagger$ Retained dose: administered dose-radioactivity excreted in urine before the flushing dose. Retained dose at the commencement of displacement studies ranged from 23.2 to $48.3 \%$ of the administered dose.

$\ddagger$ Equivalent to $15 \mathrm{mg}$ of the biologically active $l$, L-diastereoisomer.

$4.2 \%$ when a second flushing dose of the same agent was given 2 days later.

With agents displacing only small amounts of radioactivity, the peak rate of excretion appeared to occur very shortly after the displacement dose; however, with agents displacing relatively large amounts of radioactivity, the peak rate of excretion was not reached until several hours after the flushing dose had been given (Figure 3 ).

The greater part of the radioactivity appearing in the urine during the period from 48 hours after the administration of the initial labeled dose up to the time of administration of the flushing doses consisted of labeled conversion products of methotrexate; this observation suggested that the labeled drug retained in the tissues might be undergoing a similar conversion. This was not the case; in all experiments in which sufficient radioactivity was displaced to permit chromatography to be carried out, by far the greater part of the displaced radioactivity was attributable to unchanged methotrexate (see below).

Chromatographic properties of labeled compounds in urine. Essentially all radioactivity excreted in the urine during the first few hours after administration of methotrexate- ${ }^{3} \mathrm{H}$, and over $80 \%$ of the radioactivity eliminated after the flushing doses, migrated as unchanged methotrexate when chromatographed on DEAE-cellulose (Figure 4). On the other hand, urine obtained 14 days after the initial labeled dose (several days before the flushing doses) contained two labeled compounds with chromatographic properties differing from those of methotrexate; these compounds together accounted for about $60 \%$ of the urinary radioactivity, whereas unchanged metho- 
trexate represented only about $38 \%$. Traces of these two compounds also accounted for the small amount of nonmethotrexate radioactivity that appeared in the urine after the flushing doses (Figure 4). Attempts to identify these compounds, both of which migrate more rapidly on DEAEcellulose than does methotrexate, have been hampered by the extremely low levels of radioactivity involved. The mobility of the earlier peak (Fractions 3 to 6 in Figure 4) on DEAE-cellulose is similar to that of a number of free pteridines, but the mobility of the later peak (Fractions 13 to 16) was slightly greater than that of such possible cleavage products as $N$-methyl- $p$-aminobenzoylglutamate and $p$-aminobenzoylglutamate.

\section{Discussion}

A striking difference exists between the rate of disappearance of pteroylglutamate from the plasma and that of the 4-amino-10-methyl ana$\log$, methotrexate. Comparison with earlier experiments using pteroylglutamate ${ }^{3} \mathrm{H}$, in doses ranging from 1 to $1,430 \mu \mathrm{g}$ per $\mathrm{kg}$ (9), shows that the fractional disappearance from plasma of a dose of methotrexate of $2.5 \mu \mathrm{g}$ per $\mathrm{kg}$ per unit time is comparable to the fractional disappearance of a dose of pteroylglutamate about ten times as great. Furthermore, with a dose of $2.5 \mu \mathrm{g}$ of methotrexate per $\mathrm{kg}$, about $40 \%$ of the dose appeared unchanged in the urine within 24 hours, while with similar doses of pteroylglutamate, the

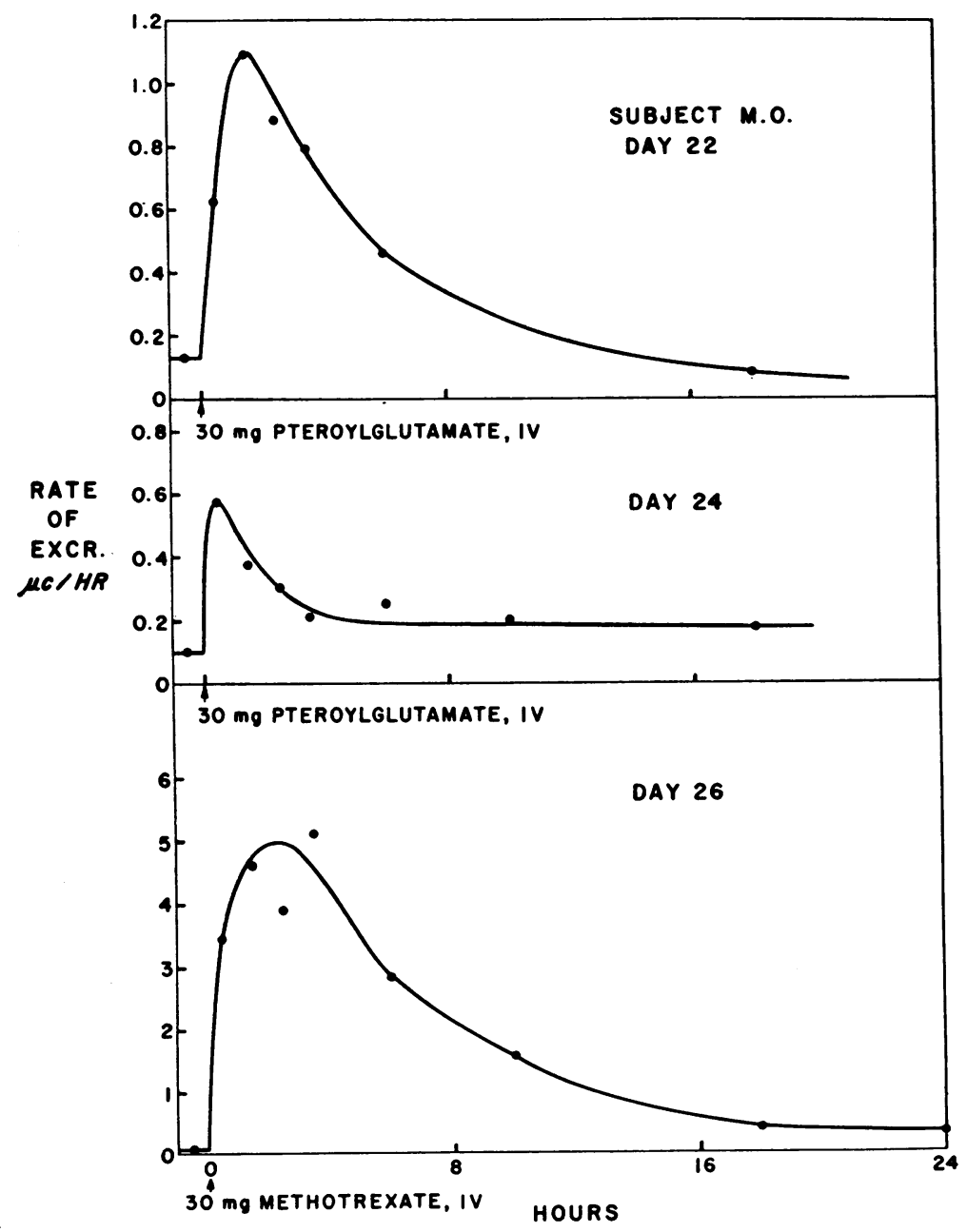

Fig. 3. Time-COURSE of RENAL EXCRETION OF RAdioactivity AFter Flushing doses of pteroylglutamate and methotrexate (Subject M.O.). 


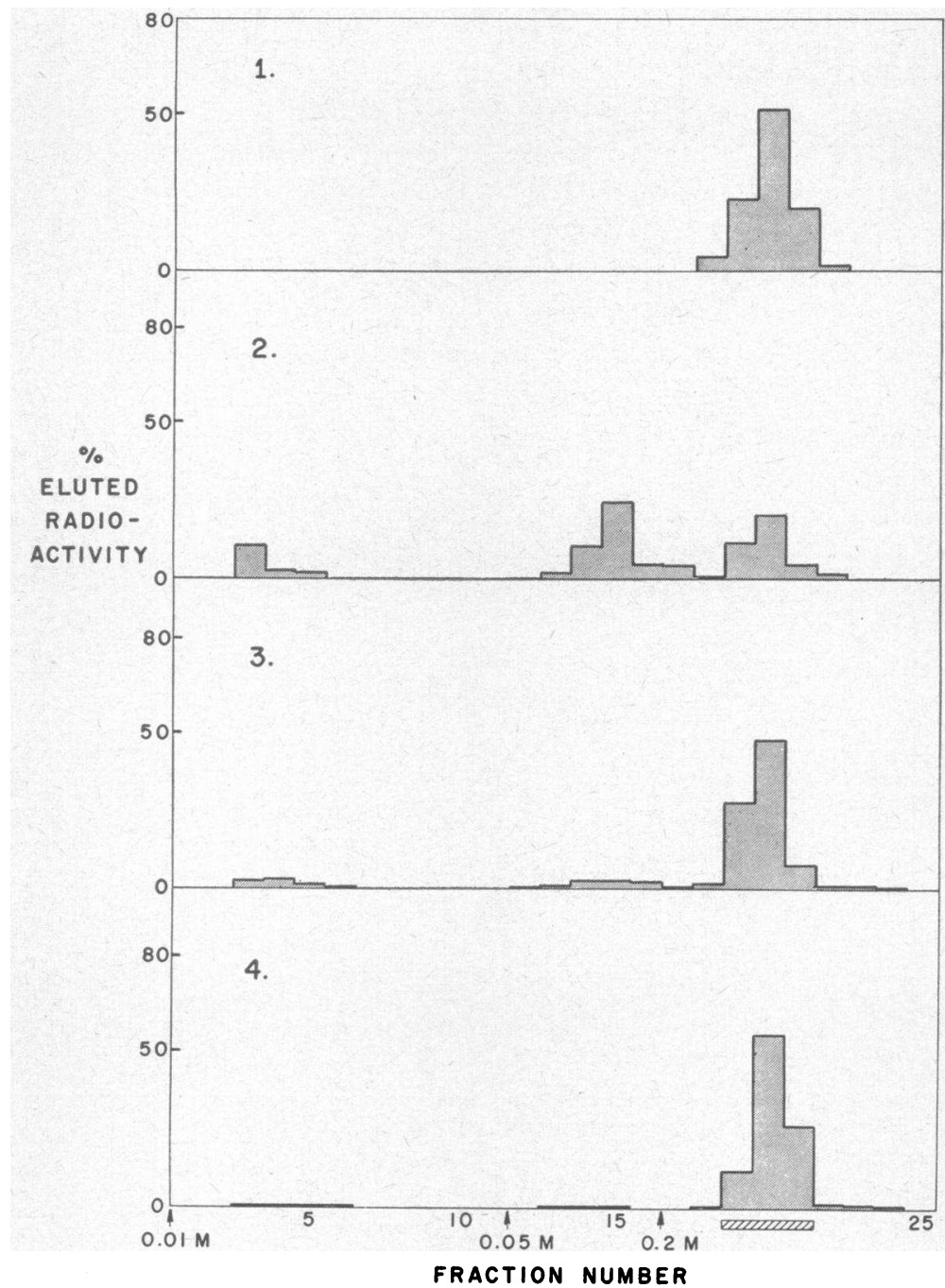

Fig. 4. Elution PRofile of RAdioactivity in the URINe AfTer the INTRAVENOUS ADMINISTRATION (SUBJECT E.B.) of $2.5 \mu \mathrm{G}$ OF TRITIUM-LABELED METHOTREXATE PER KG. Urines were chromatographed on DEAE-cellulose, with neutral phosphate buffers (see Methods). The vertical bars show the percentages of the total eluted radioactivity present in the individual fractions. Abscissa: fraction number. Fraction volume was $7 \mathrm{ml}$. Arrows indicate points at which buffer concentration was increased. Shaded horizontal bar shows region of elution of methotrexate (Fractions 19 to 21). 1. Urine collected between 1 and 2 hours after administration of labeled methotrexate. 2. Urine collected 14 days after administration of labeled methotrexate. 3. Urine collected between 1 and 2 hours after iv administration of $10 \mathrm{mg}$ of pteroylglutamate, 19 days after administration of labeled methotrexate. 4. Urine collected between 1 and 2 hours after iv administration of $10 \mathrm{mg}$ of unlabeled methotrexate, 20 days after administration of labeled methotrexate.

urinary excretion during the same period was well under $10 \%$, and most of this radioactivity represented cleavage products rather than unchanged pteroylglutamate. Thus, the rate of entry of methotrexate into cells is extremely slow, when compared with that of the parent compound, and plasma levels and the rate of renal excretion, after an equimolar dose, are relatively high. This 
initial period, representing the clearance of free drug from plasma, lasts at this dosage level in man only some 24 to 48 hours; the loss of bound methotrexate from tissues proceeds very much more slowly, and, as discussed below, appears to be associated with metabolic alteration of the drug.

The results obtained in the displacement experiments are compatible with the hypothesis that, in man, methotrexate is retained within cells unchanged, reversibly bound to the enzyme dihydrofolate reductase. ${ }^{8}$ Thus, those compounds that possess high affinity for the enzyme are effective methotrexate-displacing agents, whereas those compounds with low affinity are relatively ineffective (Table II). The ability of a compound to overcome the toxicity of methotrexate does not depend on its ability to displace bound methotrexate. Thus, 5-formyltetrahydropteroylglutamate (23) and 5-methyltetrahydropteroylglutamate (24) are

\footnotetext{
8 Average dihydrofolate reductase activity present in biopsy specimens of normal human liver is $0.009 \mathrm{U}$ per mg wet weight (21). Since one unit of enzyme activity can bind $4.7 \times 10^{-11}$ moles of methotrexate (22), the total enzyme present in a normal liver of $1.4 \mathrm{~kg}$ should be capable of binding $269 \mu \mathrm{g}$ of methotrexate; thus the level of liver enzyme alone is more than sufficient to account for the total methotrexate retained by the experimental subjects (44.4 to $62.2 \%$ of a dose of $2.5 \mu \mathrm{g}$ per $\mathrm{kg}$ ).
}

highly effective antidotes for methotrexate, probably acting as a source of reduced coenzyme distal to the blocked enzyme, but, as shown here, are relatively ineffective as methotrexate-displacing agents ; pteroylglutamate, on the other hand, is effective in displacing methotrexate but, if administered subsequent to methotrexate, cannot overcome methotrexate toxicity (24); dihydropteroylglutamate is effective both in displacing methotrexate, as shown here, and in overcoming methotrexate toxicity $(24,25)$. On the basis of the latter observation, Condit and Mead (25) and Mead and associates (24) have postulated that dihydropteroylglutamate may be reduced to biologically active tetrahydro forms by a methotrexate-insensitive route not requiring the enzyme dihydrofolate reductase. Dihydropteroylglutamate, however, in addition to being an effective methotrexate-displacing agent (Tables I and II), is reduced by the enzyme much more rapidly than is pteroylglutamate; thus, at $\mathrm{pH} 5.0$ (the optimal $\mathrm{pH}$ for the reduction of pteroylglutamate), the maximal reaction velocity for the enzymatic reduction of pteroylglutamate is only one-fifteenth that for dihydropteroylglutamate, and at higher $\mathrm{pH}$-levels, this difference in rate becomes even more marked until, at $\mathrm{pH} 7$, the difference is several hundredfold (22). As a result, although both pteroylglutamate and dihydropteroylglutamate can compete

TABLE II

Dihydrofolate reductase affinity of compounds tested for ability to displace tritium-labeled methotrexate

\begin{tabular}{|c|c|c|}
\hline Displacing agent & $\begin{array}{l}\text { Displacement } \\
\% \text { of retained } \\
\text { dose }\end{array}$ & $\mathrm{K}_{\mathrm{m}}$ or $\mathrm{K}_{\mathbf{i}}$ \\
\hline $\begin{array}{l}\text { Methotrexate, } \\
10-30 \mathrm{mg}\end{array}$ & $32.0-67.7$ & $\begin{array}{r}6.7 \times 10^{-10}(\mathrm{pH} 7.5)(22)^{*} \\
<1.5 \times 10^{-10}(\mathrm{pH} 6.1)(3)\end{array}$ \\
\hline $\begin{array}{l}\text { Dihydropteroylglutamate, } \\
10 \mathrm{mg}\end{array}$ & 13.8 & $\begin{array}{l}1.3 \times 10^{-6}(\mathrm{pH} 7.5)(22) \\
5 \times 10^{-7}(\mathrm{pH} \mathrm{7.5)(6)} \\
8.6 \times 10^{-6}(\mathrm{pH} \mathrm{5.2)(5)}\end{array}$ \\
\hline $\begin{array}{l}\text { Pteroylglutamate, } \\
10-30 \mathrm{mg}\end{array}$ & $4.2-9.1$ & $\begin{array}{l}7.4 \times 10^{-6}(\mathrm{pH} 5.9)(22) \\
2.3 \times 10^{-6}(\mathrm{pH} 6.0)(27) \\
7.9 \times 10^{-6}(\mathrm{pH} \mathrm{5.2)(5)}\end{array}$ \\
\hline $\begin{array}{l}d l, \mathrm{~L}-5 \text {-Formyltetra- } \\
\text { hydropteroylglu- } \\
\text { tamate, } 30 \mathrm{mg}\end{array}$ & 1.5 & $1 \times 10^{-4}(\mathrm{pH} 7.5) \dagger$ \\
\hline $\begin{array}{l}l \text {,L-5-Methyltetra- } \\
\text { hydropteroylglu- } \\
\text { tamate, } 7 \mathrm{mg}\end{array}$ & 0.4 & $>1 \times 10^{-4}(\mathrm{pH} 7.5) \dagger$ \\
\hline
\end{tabular}

* Numbers in second set of parentheses are reference numbers.

$\dagger$ Enzyme from Ehrlich ascites cells (21). 
successfully with methotrexate for enzyme sites when administered in very large doses, the difference in the rate of reduction of these compounds at the enzyme sites thus made accessible, rather than a difference in the route of reduction, may account for the fact that dihydropteroylglutamate is converted to the tetrahydro forms in significant amounts in the presence of methotrexate, whereas pteroylglutamate is not.

The presence in the urine of products of the metabolic alteration of methotrexate may provide an explanation for the gradual loss of the bound compound from tissues that has been described for a number of species, including man. As Werkheiser has pointed out (26), the affinity between methotrexate and enzyme is so great that loss of methotrexate from intact cells in which surplus enzyme is available would appear to be very unlikely. Furthermore, if, at cell death, bound methotrexate is released unchanged, many more intact cells with a full complement of enzyme are available in the immediate vicinity to act as potential binding sites. If, however, either in the intact cell or at the time of cell death, bound methotrexate is converted to metabolic derivatives ${ }^{9}$ with little or no affinity for enzyme, then a gradual loss of the drug from tissue would be expected.

\section{Summary}

Tritium-labeled methotrexate was administered intravenously to human subjects at a dosage level of $2.5 \mu \mathrm{g}$ per $\mathrm{kg}$. The rate of entry of the compound into cells was much lower than that observed previously with equimolar amounts of the parent compound, pteroylglutamate.

The renal excretion of the labeled drug, at a dosage level of $2.5 \mu \mathrm{g}$ per $\mathrm{kg}$, could be divided into an initial phase of about 48 hours, during which about $40 \%$ of the administered radioactivity was excreted unchanged, and a second phase, lasting for several weeks, during which 1 to $2 \%$ of the retained labeled drug was excreted per day, largely in the form of two conversion products.

\footnotetext{
${ }^{9}$ Of the products resulting from the in vitro reductive cleavage of methotrexate, $N$-methyl-p-aminobenzoylglutamate possesses no detectable affinity for the enzyme [enzyme from Ehrlich ascites cells (21)], but the 2,4-diaminopteridines have $\mathrm{K}_{1}$-values for dihydrofolate reductase that are greater than $1 \times 10^{-6}$ (27).
}

The unreduced compounds pteroylglutamate and methotrexate were effective in displacing bound drug, as was the partially reduced compound dihydropteroylglutamate; the fully reduced tetrahydro forms tested were relatively ineffective as displacing agents. On chromatography, the displaced radioactivity was found, in all cases, to represent unchanged methotrexate. The results are compatible with findings in other species that methotrexate is retained in cells bound to the enzyme dihydrofolate reductase.

\section{References}

1. Fountain, J. R., D. J. Hutchinson, G. B. Waring, and J. H. Burchenal. Persistence of amethopterin in normal mouse tissues. Proc. Soc. exp. Biol. (N. Y.) 1953, 83, 369.

2. Charache, S., P. T. Condit, and S. R. Humphreys. Studies on the folic acid vitamins. IV. The persistence of amethopterin in mammalian tissues. Cancer 1960, 13, 236.

3. Werkheiser, W. C. Specific binding of 4-amino folic acid analogues by folic acid reductase. J. biol. Chem. 1961, 236, 888.

4. Werkheiser, W. C. The relation of folic acid reductase to aminopterin toxicity. J. Pharmacol. exp. Ther. 1962, 137, 167.

5. Zakrzewski, S. F., and C. A. Nichol. Evidence for a single enzyme reducing folate and dihydrofolate. J. biol. Chem. 1960, 235, 2984.

6. Nath, R., and D. M. Greenberg. Dihydrofolic acid reductase of calf thymus. Biochemistry 1962, 1 , 435.

7. Osborn, M. J., M. Freeman, and F. M. Huennekens. Inhibition of dihydrofolic reductase by aminopterin and amethopterin. Proc. Soc. exp. Biol. (N. Y.) 1958, 97, 429.

8. Blakley, R. L., and B. M. McDougall. Dihydrofolic reductase from Streptococcus faecalis R. J. biol. Chem. 1961, 236, 1163.

9. Johns, D. G., S. Sperti, and A. S. V. Burgen. The metabolism of tritiated folic acid in man. J. clin. Invest. 1961, 40, 1684.

10. Sheehy, T. W., R. Santini, Jr., R. Guerra, R. Angel, and I. C. Plough. Tritiated folic acid as a diagnostic aid in folic acid deficiency. J. Lab. clin. Med. 1963, 61, 650.

11. Johns, D. G., and I. H. Plenderleith. Folic aciddisplacement in man. Biochem. Pharmacol. 1963, $12,1071$.

12. Seeger, D. R., D. B. Cosulich, J. M. Smith, Jr., and M. E. Hultquist. Analogs of pteroylglutamic acid. III. 4-Amino derivatives. J. Amer. chem. Soc. 1949, 71, 1753.

13. Mallette, M. F., E. C. Taylor, Jr., and C. K. Cain. Pyrimido (4,5-b) pyrazines. II. 2,4-Diaminopy- 
rimido (4,5-b) pyrazine and derivatives. J. Amer. chem. Soc. 1947, 69, 1814.

14. Furst, M., H. Kallmann, and F. H. Brown. Increasing fluorescence efficiency of liquid-scintillation solutions. Nucleonics 1955, April, 13, 58.

15. Langham, W. H., W. J. Eversole, F. N. Hayes, and T. T. Trujillo. Assay of tritium activity in body fluids with use of a liquid scintillation system. J. Lab. clin. Med. 1956, 47, 819.

16. Futterman, S. Enzymatic reduction of folic acid and dihydrofolic acid to tetrahydrofolic acid. J. biol. Chem. 1957, 228, 1031.

17. Blakley, R. L. Crystalline dihydropteroylglutamic acid. Nature (Lond.) 1960, 188, 231.

18. Mathews, C. K., and F. M. Huennekens. Enzymatic preparation of the l,L-diastereoisomer of tetrahydrofolic acid. J. biol. Chem. 1960, 235, 3304.

19. Keresztesy, J. C., and K. O. Donaldson. Synthetic prefolic A. Biochem. biophys. Res. Commun. 1961, 5, 286.

20. Sakami, W., and I. Ukstins. Enzymatic methylation of homocysteine by a synthetic tetrahydrofolate derivative. J. biol. Chem. 1961, 236, PC50.
21. Bertino, J. R. Unpublished data.

22. Bertino, J. R., B. A. Booth, A. L. Bieber, R. Cashmore, and A. C. Sartorelli. Studies on the inhibition of dihydrofolate reductase by the folate antagonists. J. biol. Chem. In press.

23. Burchenal, J. H., and G. M. Babcock. Prevention of toxicity of massive doses of A-methopterin by citrovorum factor. Proc. Soc. exp. Biol. (N. Y.) 1951, 76, 382.

24. Mead, J. A. R., J. M. Venditti, A. W. Schrecker, A. Goldin, and J. C. Keresztesy. The effect of reduced derivatives of folic acid on toxicity and antileukemic effect of methotrexate in mice. Biochem. Pharmacol. 1963, 12, 371.

25. Condit, P. T., and J. A. R. Mead. Further observations on the site of action of amethopterin. Biochem. Pharmacol. 1963, 12, 94.

26. Werkheiser, W. C. The biochemical, cellular, and pharmacological action and effects of the folic acid antagonists. Cancer Res. 1963, 23, 1277.

27. Zakrzewski, S. F. The mechanism of binding of folate analogues by folate reductase. J. biol. Chem. 1963, 238, 1485. 